\title{
Teaching English as a Lingua Franca in Brazil: Insights into Materials Writing
}

\author{
Claudio de Paiva Franco ${ }^{1}$ \\ ${ }^{1}$ Department of English, Federal University of Rio de Janeiro, Rio de Janeiro, Brazil \\ Correspondence: Claudio de Paiva Franco, Department of English, Federal University of Rio de Janeiro, Rio de \\ Janeiro, Brazil. E-mail: cpaivafranco@yahoo.com.br
}

\author{
Received: April 2, $2021 \quad$ Accepted: May 4, $2021 \quad$ Online Published: May 8, 2021 \\ doi:10.5539/ijel.v11n3p62 URL: https://doi.org/10.5539/ijel.v11n3p62
}

\begin{abstract}
In this paper, I intend to examine the main English as a lingua franca (ELF) issues discussed in the National Common Curricular Base (Brasil, 2018) and compare them to the views put forward by mainstream scholars in the field (Baker, 2016, 2018; Dewey, 2007; Jenkins, 2006, 2012, 2015; Pennycook, 2006, 2009; Widdowson, 1994). In addition, as a researcher and creator of teaching materials, I intend to share some insights into materials writing by presenting the main strategies adopted in writing a series of English textbooks for pre-teens, evaluated and approved for distribution by the Brazilian Textbook Program, that I have written with Tavares (Franco \& Tavares, 2018). Therefore, I hope this article may help shed light on developing and implementing materials that adopt an ELF-oriented approach in a scenario created by the legislation and the selection of textbooks that seems to be promising for the establishment of the ELF paradigm in Brazil.
\end{abstract}

Keywords: English as a lingua franca, English language teaching, teacher education, materials writing, Brazilian education guidelines

\section{Introduction}

Even though researchers have been involved in discussions about ELF in teacher education in Brazil (Calvo \& El Kadri, 2011; Bordini \& Gimenez, 2014; Gimenez, El Kadri, \& Calvo, 2018a, 2018b; Siqueira, 2018) for almost a decade, it was not until recently that the term ELF was granted a special status in the National Common Curricular Base (henceforward BNCC, abbreviation in Portuguese) (Brasil, 2018). These are the educational guidelines that define the common core curriculum for all subjects to be taught from pre-school through upper secondary education in Brazil. In earlier Brazilian education guidelines and documents (Brasil, 1996, 1998) English was seen as a 'modern foreign language'. However, having become a compulsory subject in elementary and high school education under the BNCC, it is now viewed as a lingua franca.

Some concepts no longer seem to be in tune with the perspective of understanding a language that 'has gone viral' and has become 'miscegenated', as is the case of the concept of 'foreign language', strongly criticized for its Eurocentric bias. Other, more recently proposed, terminologies also foster an intense debate in the field, such as English as an international language, as a global language, as an additional language, as a lingua franca, among others. Despite the differences between one terminology and another, their emphases, points of contact and possible overlaps, the treatment given to the subject in the BNCC prioritizes the focus on the social and political functions of English and, in this sense, starts to deal with it in its lingua franca status. (Brasil, 2018, p. 241) (Note 1)

Jenkins (2006) summarizes the differences between ELF and English as a foreign language (henceforward EFL) by stating that ELF is part of the Global Englishes paradigm, according to which most users of English are non-native speakers, and all English varieties are acceptable in their own right. The concept of EFL, on the other hand, is part of the modern foreign languages paradigm, according to which most interactions involving non-native speakers are with native speakers of the language, and the learner's ultimate goal is (likely) to be near-native competence.

The underlying notions of ELF in the BNCC and their implications for teaching must also be adhered to by textbook writers who submit their books to be evaluated by the Brazilian Textbook Program-(henceforward PNLD, abbreviation in Portuguese)-, a federal government program that evaluates and selects textbooks to be 
distributed to all public schools in Brazil.

\section{From EFL to ELF in Brazil: What the Brazilian Education Guidelines Suggest}

At the beginning of the text devoted to English language teaching in the BNCC, it is made clear that the notion of an increasingly globalized, plural social world is fundamental to shed light on the relevance of learning the English language. According to the document,

learning the English language may allow everyone access to the necessary linguistic knowledge for engagement and participation, contributing to the students' critical agency and active citizenship, in addition to expanding their possibilities for interaction and mobility, opening new paths of knowledge construction and learning continuity. (Brasil, 2018, p. 241)

Based on this formative assessment, the BNCC lists three important functions of English language teaching (henceforward ELT): (1) to review the relations between language, territory and culture; (2) to broaden the understanding of literacy; and (3) to situate the English language in its lingua franca status.

Before delving into the first function of ELT, a brief, clear definition of ELF is necessary. Jenkins (2012, p. 486) states that 'it is a means of communication between people who come from different first language backgrounds.' In this sense, any English speaker can be an ELF speaker, be they native users of English or not. She also adds that 'ELF is not a language variety in the traditional sense of the term.'

The first ELT function described in the BNCC is in line with Jenkins's view of ELF.

In this proposal, the English language is no longer that of the 'foreigner', coming from hegemonic countries, whose speakers serve as a model to be followed, nor is it a variety of the English language. In this perspective, the uses made by speakers from all over the world, with different linguistic and cultural repertoires, are accepted and validated, which allows us, for example, to question the view that the only 'correct' English — and the one to be taught—is the one used by American and British speakers. (Brasil, 2018, p. 241)

This quote argues that treating English as a lingua franca validates the uses of the language by speakers from places where English is neither the L1 nor an official language, which is the case of Brazilian users of English. The BNCC also contributes to the ownership debate concerning the English language, which has been brought to the fore by Widdowson (1994), who points out that native speakers of English who live in the US or the UK no longer 'own' the language. Given the fact that English has become an international language, he argues that 'no nation can have custody over it' (Widdowson, 1994, p. 385).

The BNCC summarizes the first ELT function by advocating a teaching approach focused on interculturality, which entails

the recognition of (and respect for) differences, and for the understanding of how they are produced in the different social practices of language, which favors critical reflection on different ways of seeing and analyzing the world, the other(s) and yourself. (Brasil, 2018, p. 242)

Most recently, the traditional terminology 'intercultural communication' has been replaced by 'transcultural communication' (Baker, 2016, 2018; Pennycook, 2006) because it provides a better metaphor as it suggests transgressing borders.

The second ELT function described in the BNCC concerns the notion of multiliteracies, also conceived in the social practices of the digital world. A digitally-enhanced learning context creates a number possibilities for English learners to express their ideas, feelings and values.

In this sense, when assuming its status as a lingua franca - a language that materializes in hybrid uses, marked by fluidity and that opens itself up to the invention of new ways of speaking, driven by plural/multilingual speakers and their multicultural characteristics-, the English language becomes a symbolic asset for speakers around the world. (Brasil, 2018, p. 242)

As a major result of globalization, the BNCC agrees with the view of ELF scholars (Dewey, 2007; Pennycook, 2009; Jenkins, Cogo, \& Dewey, 2011) who highlight the fluidity, flexibility and hybridity of the English language.

The third and last ELT function described in the BNCC refers to teaching approaches and the need to effectively consider and teach the English language as a lingua franca. The BNCC calls into question the prioritizing of standard native English grammatical norms in assessing the competence of non-native learners.

This requires the teacher to have an attitude of acceptance and validation of different forms of expression 
in the English language, such as the use of ain't in negative sentences, and not just 'standard' forms like isn't or aren't. In other words, we do not want to treat these uses as exceptions, as local oddities of the language, which deviate from the 'standard' to be followed. Quite the contrary-the teacher is to treat local uses of English and related linguistic resources in the perspective of building a linguistic repertoire, which must be analyzed and made available to the student to make use of it, always fulfilling the condition of intelligibility in linguistic interactions. (Brasil, 2018, p. 242)

The passage also mentions that it is mandatory to respect 'the conditions of intelligibility in the linguistic interaction', which agrees with what is argued in 'It does not matter (...) whether the language conforms to established code rules or usage conventions so long as it is intelligible and pragmatically effective' (Widdowson, 2012, p. 21) in ELF communication.

After discussing the underlying views of ELT and presenting these three ELT functions, the BNCC lists the necessary competences, skills and contents to be covered in the curriculum, which are organized into five pillars: orality, reading, writing, linguistic knowledge and intercultural dimension. Apart from the well-known language skills of reading and writing, orality encompasses listening, oral interaction and oral production. Linguistic knowledge is expanded into grammar and vocabulary, and the last pillar - intercultural dimension - deals with interculturality from an ELF perspective. The BNCC states that

the treatment of English as a lingua franca imposes challenges and brings new priorities for teaching, including deeper reflections on the relations between language, identity and culture, and the development of intercultural competence. (Brasil, 2018, p. 245)

These five pillars must be taken into careful consideration when creators of teaching materials write textbooks to be evaluated and accepted into the PNLD.

\section{ELF Possibilities and Materials Writing}

In this section, I present the main strategies adopted in writing an integrated-skills, ELF-oriented series of textbooks approved by the PNLD and meant to be used exclusively in public schools. Entitled 'Way to English for Brazilian Learners of English' (Franco \& Tavares, 2018), it is a four-year series for pre-teens, aimed at Brazilian students between ages $10 / 11$ and $13 / 4$, in years $6-9$ of elementary school. The four volumes in the series follow the educational norms presented in the BNCC as described in its teacher's book:

(...) we prioritize the social and political functions of the language, which is treated in its lingua franca status. Thus, as the BNCC recommends, we do not believe that there is an English language standard to be taught or an ideal speaker model to be followed. Instead of concepts of right and wrong, students are invited to reflect on what is appropriate and intelligible in different interactions. Furthermore, we understand that, in the social practices of the digital world, knowing English enhances the possibilities of participation and it is essential that multiliteracies are also conceived in these practices, in which different languages (verbal, visual, corporal, audiovisual) come together and intertwine. (Franco \& Tavares, 2018, p. 21)

In addition to following the BNCC guidelines, the writers who submit textbooks to be evaluated and adopted by the PNLD must present a pedagogical framework in the teacher's book that explains how key elements are dealt with in the students' books, such as theoretical/methodological principles, a discussion on assessment, a description of sections, among other relevant aspects. In the series (Franco \& Tavares, 2018), we adopt the notion of genre as social action (Bazerman, 2013), thus all texts and recordings used in the series are authentic materials, rather than made to order bits of language to assist a teaching point. Our main concern is to provide learners with language that is out there, in the real world, used by speakers of English, whether they are native speakers or not, and at the same time to make sure that the language used in the series covers a broad range of language varieties.

Some of the main strategies adopted to write the student's books are listed below and illustrated by examples (see Appendices A, B and C for samples of the textbooks):

- authentic recordings of non-native Englishes (e.g., volume 3: a short documentary in which a Brazilian ballerina uses English to talk about her career; volume 4: a speech delivered in English by Malala Yousafzai at the United Nations);

- authentic written texts by non-native English users (e.g., volume 1: a text written by a Mexican child; volume 2: a transcribed speech by an Indian visual artist and other texts written by Indian users of English);

- special chapters that promote discussions about relevant issues related to language and globalization (e.g., 
volume 3, chapter 3: 'The Future of English'; volume 3, chapter 6: 'What a Wonderful World!');

- a special introductory section in each volume ('English all Around the World') that addresses issues related to World Englishes, language and globalization (e.g., volume 2: activities on the issue of ELF and different uses of the language);

- recommendation of specific websites, throughout the series and also in boxes ('Le@rning on the Web'), that provide different sources for additional content written by or for non-native English users (e.g., volume 1: activity based on an online dictionary that provides the pronunciation of words in English in different accents, not only UK and US ones; volume 1: link to a website that shows the countries where English is an official language);

- boxes ('Think about it!') that develop learners' critical thinking by discussing different social, cultural, and linguistic issues, including some related to World Englishes (e.g., volume 1: reflexive questions on the use of English by non-native speakers; volume 2: reflexive questions on the reading of a comic strip that contains non-standard forms of English);

- awareness-raising activities about language variation and World Englishes in different written and oral texts (e.g., volume 2: discussion on the effectiveness of a French photographer delivering a TED presentation in English; volume 3: discussion on the intelligibility of a recording in which a Brazilian speaker of English uses non-standard forms of the language; volume: 4: discussion on language and identity portrayed in the movie 'Spanglish').

We also thought including strategies to help teachers develop an ELF attitude towards ELT. Above and beyond what is included in the textbooks, we believe it is paramount to encourage teachers to accept and validate different forms of expression in English in the classroom. The following items are some of the main strategies we used in the teacher's book to help enhance teachers' views and attitudes:

- providing guidelines on how to deal with assessment and language correction in the classroom;

- boxes ('To learn more') that recommend academic papers, videos and websites on relevant ELT issues (e.g., volume 1: articles on teaching ELF and its teaching challenges; volume 3: articles on multiliteracies and implications to ELT; volume 4: videos on the spread of English around the world);

- complementary notes that provide detailed information on specific subjects (e.g., volume 2: notes on the use of English as a lingua franca; volume 4: colonization processes).

\section{What Next?}

The strategies presented in the previous section seem to be a first move towards designing an ELF-oriented series for Brazilian learners of English. However, the path in the direction of creating this kind of teaching material is still full of obstacles.

One of the most difficult challenges textbook writers and publishers face when using authentic materials (texts, recordings, photos) is the issue of copyrights and licensing. If materials are not licensed under a Creative Commons Attribution 4.0 - and few of them are-, it is mandatory to reach the creators or the copyright holders (who may not be the creators) and ask for their permission first. Even so, there are many possible outcomes: the best-case scenario is being able to use the material for free or at a low fee. The worst-case scenario may include having no feedback, receiving last-minute feedback when the work is almost done, being charged an impossible amount of money (at times for a short poem), or even receiving a denial.

Another challenge we face and, perhaps, a more serious one, involves implementing a national policy on ELF in Brazil in the sense that what is prescribed in the BNCC is effectively carried out in the classroom. Despite the fact that this paper focuses on ELF concerning materials writing, we must consider that the textbook is an important resource in the classroom but not the only one. Another resource precedes it, and this is a human one- the teacher. It is somehow pointless to use an ELF-oriented series if the teacher's attitude towards ELT is still EFL-oriented. For example, if students perform well on a role-play activity, using efficient and intelligible language, but use non-standard forms of the language (e.g., zero marking of third person present singular -s, as in 'she say'), why does the prevailing guideline in ELT still leans towards native correctness regardless of the communication context?

I strongly believe that there is fertile ground for the teaching ELF in Brazil. Even though the PNLD is a federal-level program famous for the large number of textbooks it purchases and distributes to public schools, it is not enough to distribute ELF-oriented textbooks to public schools if no investment is made in teacher education. A more concrete move towards enhancing ELT teacher education in Brazil may take place on a 
state-municipal level with local initiatives supported by the academic community. The articulation between the three levels of government in Brazil-federal, state and municipal - is crucial to put into practice what the BNCC suggests and to bring schools and universities closer together. In doing so, both levels of education may benefit from a partnership through which university professors and researchers and schoolteachers can engage in fruitful discussions and exchange experiences, beliefs and values.

\section{References}

Baker, W. (2016). English as an academic lingua franca and intercultural awareness: Student mobility in the transcultural university. Language and Intercultural Communication, 16(3), 437-451. https://doi.org/10.1080/14708477.2016.1168053

Baker, W. (2018). English as a lingua franca and intercultural communication. In J. Jenkins, W. Baker \& M. Dewey (Eds.), The Routledge Handbook of English as a Lingua Franca (pp. 25-36). London \& New York: Routledge. https://doi.org/10.4324/9781315717173-3

Bazerman, C. (2013). Genre as Social Action. In J. Gee \& M. Handford (Eds.), The Routledge Handbook of Discourse Analysis (pp. 226-238). London \& New York: Routledge.

Bordini, M., \& Gimenez, T. (2014). Estudos sobre inglês como língua franca no Brasil (2005-2012): uma metassíntese qualitativa. Signum: Estudos da Linguagem, 17(1), 10-43. https://doi.org/10.5433/2237-4876.2014v17n1p10

Brasil. (1996). Lei $n^{o}$ 9.394, de 20 de dezembro de 1996. Retrieved from http://www.planalto.gov.br/ccivil_03/leis/19394.htm

Brasil. (1998). Parâmetros Curriculares Nacionais: terceiro e quarto ciclos do ensino fundamental: língua $\begin{array}{lllll}\text { estrangeira. } & \text { Ministério } & \text { da } & \text { Educação. } & \text { Retrieved }\end{array}$ http://portal.mec.gov.br/seb/arquivos/pdf/pen_estrangeira.pdf

Brasil. (2018). Base Nacional Comum Curricular. Ministério da Educação. Retrieved from http://basenacionalcomum.mec.gov.br/images/BNCC_EI_EF_110518_versaofinal_site.pdf

Calvo, L., \& El Kadri, M. (2011). Mapeamento de estudos nacionais sobre Inglês como Língua Franca. In T. Gimenez, L. Calvo \& M. El Kadri (Eds.), Inglês como língua franca: ensino-aprendizagem e formação de professores (pp. 17-44). Campinas: Pontes.

Dewey, M. (2007). English as a lingua franca: An interconnected perspective. International Journal of Applied Linguistics, 17(3), 332-354. https://doi.org/10.1111/j.1473-4192.2007.00177.x

Franco, C., \& Tavares, K. (2018). Way to English for Brazilian Learner of English (2nd ed.). São Paulo: Ática.

Gimenez, T., El Kadri, M., \& Calvo, L. (2018a). ELF in Brazil: Recent developments and further directions. In J. Jenkins, W. Baker \& M. Dewey (Eds.), The Routledge Handbook of English as a Lingua Franca (pp. 176-187). London \& New York: Routledge. https://doi.org/10.4324/9781315717173-15

Gimenez, T., El Kadri, M., \& Calvo, L. (2018b). Awareness raising about English as a lingua franca in two Brazilian teacher education programs. In T. Gimenez, M. El Kadri \& L. Calvo (Eds.), English as a global lingua franca and language education: A Brazilian perspective (pp. 211-230). Berlin: De Gruyter Mouton. https://doi.org/10.1515/9781501503856-011

Jenkins, J. (2006). Points of view and blind spots: ELF and SLA. International Journal of Applied Linguistics, 16(2), 137-162. https://doi.org/10.1111/j.1473-4192.2006.00111.x

Jenkins, J. (2012). English as a Lingua Franca from the classroom to the classroom. ELT Journal, 66(4), 486-494. https://doi.org/10.1093/elt/ccs040

Jenkins, J. (2015). Repositioning English and multilingualism in English as a lingua franca. Englishes in Practice, 2(3), 49-85. https://doi.org/10.1515/eip-2015-0003

Jenkins, J., Cogo, A., \& Dewey, M. (2011). Review of developments in research into English as a lingua franca. Language Teaching, 44(3), 281-315. https://doi.org/10.1017/S0261444811000115

Pennycook, A. (2006). Global Englishes and Transcultural Flows. London \& New York: Routledge. https://doi.org/10.4324/9780203088807

Pennycook, A. (2009). Plurilithic Englishes: Towards a 3D model. In K. Murata \& J. Jenkins (Eds.), Global Englishes in Asian contexts (pp. 194-207). Basingstoke: Palgrave Macmillan. https://doi.org/10.1057/9780230239531_12 
Siqueira, S. (2018). English as a lingua franca and teacher education: critical educators for an intercultural world. In T. Gimenez, M. El Kadri \& L. Calvo (Eds.), English as a global lingua franca and language education: A Brazilian perspective (pp. 87-114). Berlin: De Gruyter Mouton. https://doi.org/10.1515/9781501503856-006

Widdowson, H. (1994). The Ownership of English. TESOL Quarterly, 28(2), 377-389. https://doi.org/10.2307/3587438

Widdowson, H. (2012). ELF and the inconvenience of established concepts. Journal of English as a Lingua Franca, 1(2), 187-193. https://doi.org/10.1515/jelf-2012-0002

\section{Note}

Note 1 . All the translations in this paper are by the author.

\section{Appendix A}

Authentic recordings of non-native Englishes

\section{(9) Listening and Speaking}

(1) Take a look at the following picture and based on what you know about the woman in the photo, ask and answer the questions below in pairs.
a. What is her name? Ingrid Silva.
b. Where is she from? Brazil.
c. Where does she live? New York City.
d. What is her occupation? Ballerina./Ballet dancer.

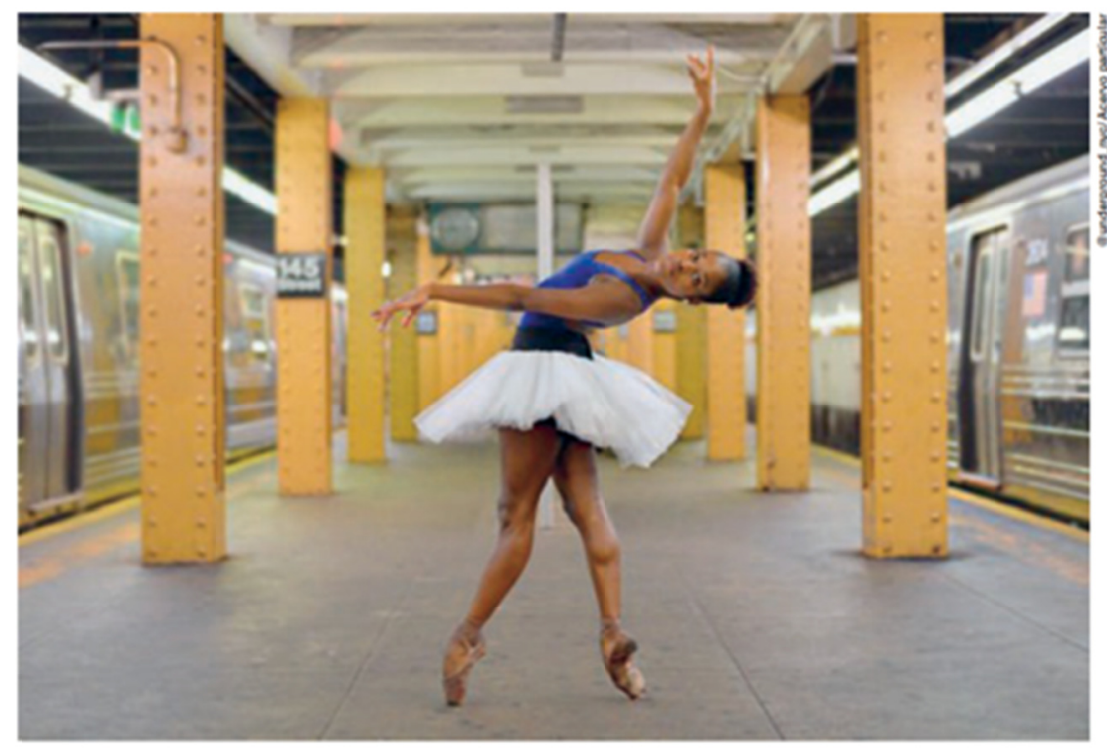

72 Now listen to a short documentary about Ingrid Silva produced by Health's \#ReallifeStrong series. What does she say about ballet? Choose $\mathbf{a}$ or $\mathbf{b}$ and write the answer in your notebook.
a. Ballet is an elite art form. It's done by one person.
b. Ballet never gets perfect. It takes perseverance and patience. $x$

\section{Le@rning} on the Web

Criado em 1995 , o projeto Dançando Para Não Dançar oferece suporte socioeducativo a crianças de mais de dez comunidades 
$\gamma$ (3) Listen to the recording again and, in your notebook, write $\mathbf{T}$ (True) or $\mathbf{F}$ (False). Then, correct the false statements.

a. She started dancing at the age of eight. T

b. She participated in a dance community project in Brazil called Dançando Para Não Dançar. T

c. She mentions that there are many black ballerinas in Brazil.

d. She works eight hours a day, every day. F: She works

e. She has a dog called Frida. T

seven hours a

F: She mentions that there aren't

many black

ballerinas in Brazil. 2 and 3 .

5 When talking about the ballet career, Ingrid says that "There will be many ups and downs." What does the expression in bold mean? Choose $\mathbf{a}$ or $\mathbf{b}$ and write the answer in your notebook.

a. A mess, a state of disarray.

b. Good times and bad times, successes and failures. $x$

\section{Think about it!}

Ingrid Silva é brasileira, mora nos Estados Unidos e usa a língua inglesa no seu cotidiano para se comunicar com pessoas de diferentes lugares. No trecho do documentário produzido pela revista Health, "I didn't have no idea that I could become a professional dancer (..) there is not many black ballerinas.", percebemos que há dois exemplos (grifados em negrito) de uso da língua que não estão de acordo com o que está prescrito na norma-padrăo (any e are, respectivamente). Na sua opinião, isso comprometeu a mensagem que Ingrid gostaria de transmitir? Por quê (não)? Para você, o que pode impedir o entendimento entre pessoas de culturas diferentes que falam a língua inglesa? Respostas pessoais.

(6) Are there any dance projects in your community like Dançando Para Não Dançar? If so, what are they? Personal answers.

7 Discuss the questions below with your classmates. Use expressions from the Language Note box to help you. Personal answers.

a. Ingrid Silva is an example of a successful ballerina because of her perseverance and hard work. She also mentions that these characteristics have helped her as a woman. In your view, what other characteristics are important for someone to grow as a human being?

b. Ingrid believes it is important to have someone who looks like you as a role model because it gives you more power, inspiration and dreams. Do you agree with her? Who is your role model? Why? da cidade do Rio de Janeiro. Além das aulas de dança, as crianças têm aula de idiomas (inglês e alemăo) $\mathrm{e}$ reforço escolar. Para conhecer mais sobre o projeto, visite. $<$ www.dpnd. org $>$. Acesso em: 10 jul. 2018.

\section{Language} Note

Asking for an opinion: What do you think?/Do you agree?/How do you feel about that?

Expressing an opinion: In my opinion_/ $/$ believe that._./In my view...

Agreeing: I agree with you/l guess you're right/. Absolutely -Tell me about it!

Disagreeing: | don't agree with you/I totally disagree /l'm afraid that's not true.

\section{Le@rning}

\section{on the Web}

Além de Ingrid

Silva, existem outros dois brasileiros que fazem parte da Dance Theatre of Harlem (Dylan Santos, de São Paulo, e Alison Stroming, do Recife). Para

Figure A1. A sample of the section 'Listening and Speaking', which contains activities based on an authentic recording of non-native English (volume 3) 


\section{Appendix B}

Special chapters that promote discussions about relevant issues related to language and globalization

\section{Before Reading}

(1) In your opinion, is English an easy or difficult language to learn? Why? Personal answers.

(2) Before reading the following text, take a look at its title, subtitle and source.

What do you expect to read about? Suggested answers: The future of

English/English is becoming a simpler

Reading

language, spoken by many foreigners.

Now read the text below to check your predictions.

\section{- $\rightarrow \mathrm{C}$ inww.economist.com \\ Future English \\ Johnson: Simpler and more foreign \\ A few guesses as to what English will look like in the coming decades and centuries}

Prospero>

Jul 3 2014 | by R.L.G. | BERLIN

SEVERAL weeks ago, Johnson discussed his debate with Nicholas Ostler about the lingua franca of the future. Johnson thinks that English has a very long run ahead of it. Mr. Ostler sees English's time as coming to an end, to be replaced by machinetranslation tools that will remove the need

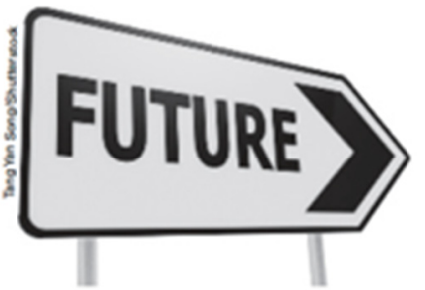

for people to learn to speak, read and write a lingua franca. But we agreed that whatever the long run might look like, the next few decades are set. No language has anything like a chance of displacing English.

Interestingly, about two-thirds of English-speakers are not first-language speakers of English. To put it another way: English no longer belongs to England, to superpower America, or even to the English-speaking countries generally. Rather, English is the world's language. What happens to a language when it becomes everybody's? Shaped by the mouths of billions of non-native speakers, what will the English of the future look like?

A look into the past can give us an idea. English is of course not the first language learned by lots of non-natives. When languages spread, they also change. (...)

English may simplify because it is spreading. But it is spreading because it is expressive and useful. Most of the world's languages would love to have the problems that English has.

Available at: <www.economistcom/prospero/2014/07/03/johnson-simpler-and-more-foreign > Accessed on: July 15, 2019. (Fragment).

\section{foreign}

/fo:ran/

adjective

in or from a

country that is not yours.

- estrangeiro 


\section{Reading for General Comprehension}

Based on the author's point of view, what is the future of English? Choose $\mathbf{a}$ or $\mathbf{b}$ and write the answer in your notebook.

a. English will never grow in usage and variety.

b. English may simplify because it is being used by more and more people. $x$

\section{Reading for Detailed Comprehension}

(1) Johnson is a journalist who works for The Economist, a weekly British newspaper. Who is Nicholas Ostler? Make inferences. Choose $\mathbf{a}$ or $\mathbf{b}$ and write the answer in your notebook.

a. He is a language specialist. $x$

b. He is an economic specialist.

2 What do they say about the future of English? In your notebook, write (I) if the sentence refers to Johnson's opinion, (II) if it refers to Mr. Ostler's opinion or (III) if it refers to the opinion of both.

a. English has a great future ahead of it. I

b. No language will take the place of English in the next few decades. III

c. People will use machine-translation tools to communicate. ॥

(3) According to the text, choose the terms below that can be used to refer to English. Write the answers in your notebook.
a. "world's language" $x$
c. "belongs to England"
b. "expressive and useful" $x$
d. "belongs to superpower America"

(4) Choose the pie chart below that best illustrates the fragment "about twothirds of English-speakers are not first-language speakers of English". Write the answer in your notebook.

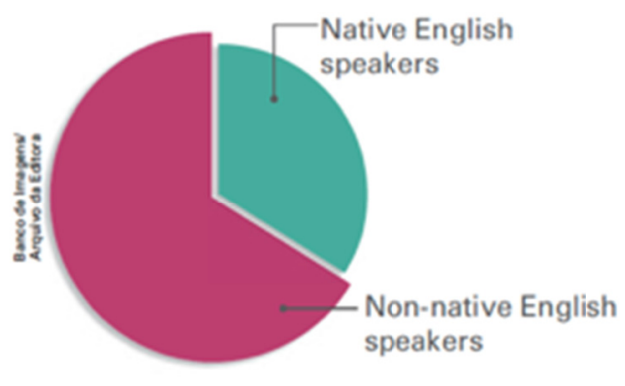

a. $\mathrm{x}$

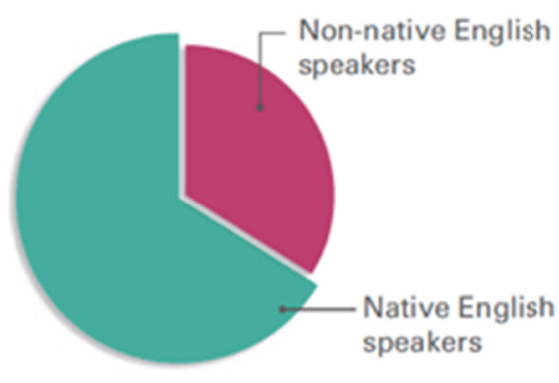

b.

(5) Choose the correct statement about the fragment "Most of the world's languages would love to have the problems that English has". Write the answer in your notebook.

a. The fact that English is spreading is something negative.

b. The fact that English is spreading is something positive. $x$ 


\section{Reading for Critical Thinking}

Discuss the questions below with your classmates. Personal answers.

a. According to Nicholas Ostler, English is "to be replaced by machinetranslation tools that will remove the need for people to learn to speak. read and write a lingua franca". In your opinion, can digital tools completely replace the need for people to learn a lingua franca like English? Why (not)?

b. The text mentions language simplification as one of the consequences of the global spread of the English language. In your opinion, does the spread of English bring more advantages or disadvantages? Why?

tip
Procure ter uma
postura critica
diante dos textos,
considerando
novas
perspectivas
sobre o tema e
relacionando-o
com a realidade à
sua volta.

Figure B1. A sample of the chapter 'The Future of English' (volume 3), which promotes discussions about relevant issues related to language and globalization

\section{Appendix C}

A special introductory section in each volume ('English all Around the World') that addresses issues related to World Englishes, language and globalization

\section{English All Around the World}

Nesta seção, você vai analisar o alcance da língua inglesa e os seus contextos de uso no mundo globalizado. Antes de você ler os textos a seguir e explorar a abrangência da língua inglesa, responda em seu caderno:

Na sua opinião, há mais falantes de inglês como língua materna ou pessoas que usam a língua inglesa e têm outro idioma como lingua materna? Resposta pessoal.

Agora leia os textos abaixo e responda às questões a seguir em seu caderno.

\section{Text 1}

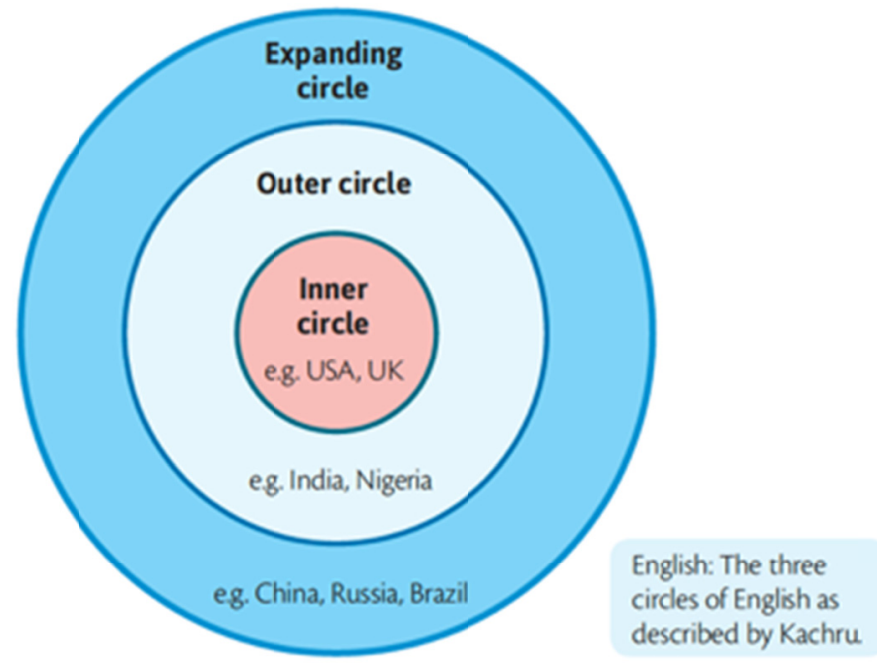


Text 2

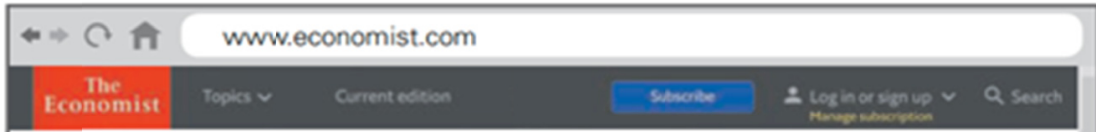

(...) Interestingly, about two-thirds of English-speakers are not firstlanguage speakers of English. To put it another way: English no longer belongs to England, to superpower America, or even to the Englishspeaking countries generally. Rather, English is the world's language. (...)

about two-thirds = cerca de dois terços

belong = pertencer rather $=$ em vez disso

Available at: <wwweconomist.com/blogs/prospero/2014/07/future-english>.

Accessed or June 25, 2018. (Fragment).

Com base no primeiro texto, correlacione as colunas abaixo. Escreva as respostas em seu caderno.
a. Círculo interno (Inner circle) ॥
I. Paises onde a lingua inglesa é usada como lingua
b. Circulo externo (Outer circle) III internacional (international language).
c. Círculo em expansão (Expanding circle)।
II. Paises onde a língua inglesa é usada como primeira língua (first language) ou língua materna (mother tongue).
III. Paises onde a lingua inglesa é usada como segunda lingua (second language).

(2) Responda às perguntas a seguir em seu caderno.
a. Em quais paises mencionados no primeiro texto, o inglês é falado como primeira língua ou língua materna? Estados Unidos (USA), Reino Unido (UK).
b. E como segunda língua? india, Nigéria.
c. E como lingua internacional? China, Rússia, Brasiil.

(3) Você sabe em quais outros países a língua inglesa é utilizada como língua materna? Faça uma busca na internet e escreva a resposta em seu caderno. Canadá, Austrália e Nova Zelăndia.

(4) Em seu caderno, responda às questões abaixo sobre o segundo texto.
a. A quais falantes de inglês a expressão "about two-thirds of English-speakers" (cerca de dois terços dos falantes de inglês) se refere?

$\Delta$ À quantidade de falantes nativos de inglês, ou seja, aqueles que falam o idioma como língua materna.

- À quantidade de falantes não nativos de inglês, ou seja, aqueles que falam o idioma como segunda língua ou língua internacional. $x$

b. No segundo texto, qual expressão é utilizada para se referir à língua inglesa como língua global, utilizada por falantes nativos e não nativos? "the world's language" 
5 O que os dois textos da página anterior têm em comum?

$\Delta$ Ambos informam que o número de pessoas que usam a língua inglesa e têm outro idioma como língua materna é maior do que a quantidade de falantes nativos de inglês. $x$

- Ambos destacam que a língua inglesa pertence a países como Estados Unidos e Reino Unido, onde esse idioma é utilizado com língua oficial.

Think about it!

Retome a pergunta feita antes da leitura dos dois textos desta seçăo. Sua previsăo foi confirmada? Ao ler o segundo texto, você descobriu que dois terços dos falantes de inglês são non-native speakers, ou seja, falantes que não têm o idioma como sua língua matema. Os falantes nativos (native speakers) de inglês săo, portanto, a minoria. $\mathrm{Na}$ sua opiniăo, por que isso acontece? Respostas pessoais.

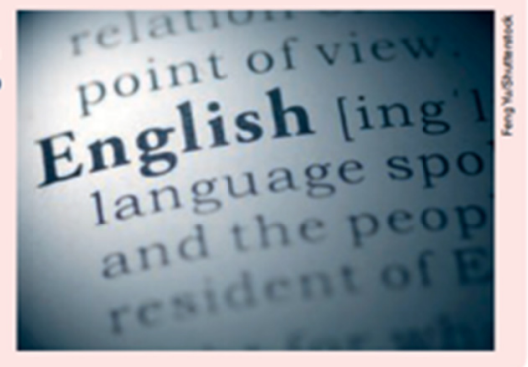

Figure C1. A sample of the special introductory section 'English all Around the World' (volume 2), which addresses issues related to ELF and different uses of the language

\section{Copyrights}

Copyright for this article is retained by the author, with first publication rights granted to the journal.

This is an open-access article distributed under the terms and conditions of the Creative Commons Attribution license (http://creativecommons.org/licenses/by/4.0/). 